\title{
Original Research \\ Hydrophysical and Biological Properties of Sandy Substrata Enriched with Hydrogel
}

\author{
Agnieszka Baran $^{1 *}$, Tomasz Zaleski², Edward Kulikowski ${ }^{3}$, Jerzy Wieczorek ${ }^{1}$ \\ ${ }^{1}$ Department of Agricultural and Environmental Chemistry, Agricultural University of Krakow, \\ Mickiewicza 21, 31-120 Krakow, Poland \\ ${ }^{2}$ Department of Soil Science and Soil Protection, Agricultural University of Krakow, \\ Mickiewicza 21, 31-120 Krakow, Poland \\ ${ }^{3}$ ARTAGRO Sp. z o.o Krakow, Poland \\ Received: February 8, 2013 \\ Accepted: August 28, 2015
}

\begin{abstract}
Our paper aims to assess the effect of Agroaquagel hydrogel on the changes of hydrophysical and biological properties of the unproductive chemically degraded soil and tailings. The experiment used two substrata: soil-loamy sand (P1) and tailings-sand (P2). The scheme of the experiment comprised five treatments: $0,0.2 \%, 0.6 \%, 1 \%$, and $2 \%$ doses of hydrogel. Hydrogel addition improved water retention capacity in both the studied P1 and P2 substrata. Increasing hydrogel dose was accompanied by a progressive increase in water retention capacity and retention of available water for plants, whereas drainage capacity decreased in relation to the control treatments. Soil and tailings enriched with the hydrogel supplement revealed a lower rate of drying, which limits the loss of water available to plants. The applied hydrogel positively affected plant growth during drought stress. The presented investigations revealed that in drought conditions, young plants growing in the substrata without hydrogel were able to survive for a maximum of five days, whereas in the treatments with $0.2-1 \%$ hydrogel supplements they survived for up to 15 and 10 days in the case of P1 and P2, respectively. The plant survivability period during drought was extended by $66 \%$ on soil (P1) and by $39 \%$ on tailings (P2).
\end{abstract}

Keywords: hydrogel, sandy substrates, water retention, drought stress, plant survivability

\section{Introduction}

Degraded or unproductive areas are characterized by deficiency of moisture and nutrients during the vegetation period. Such areas include: particularly water and nutrient-deficient sandy soils, dunes, post-industrial areas (sandpits, dumping grounds, deposited flotation tailing wastes, gravel pits), but also dewatered muck soils and peat-muck soils $[1,2]$. Disadvantageous growth conditions in these areas lead to poor plant growth and plant withering, which makes their

*e-mail: Agnieszka.Baran@ur.krakow.pl baranaga1@wp.pl recultivation difficult. The main problem encountered in these terrains is their low water retention and lack of retention capacity of water necessary for plants during their vegetation $[3,4]$. This is especially important during the first stages of plant development. Long rainless periods at the initial stage of germination and plant growth may negatively affect growth and yield of plants. The other environmental problem connected with post-industrial areas, e.g. flotation tailings, is the high content of heavy metals. The unfavourable impact of flotation tailings on the environment is pollution of ground water and surface water, dust caused by wind erosion, and infiltration of supernatant water $[5,6]$. 
The application of synthetic gel polymers is considered one possible solution to this problem, as well as a way to improve soil structure and its water-air properties [4, 7-11]. Hydrogels, which have been in use since the 1960s in various branches of chemical and pharmaceutical industries, have also found applications in agriculture, horticulture, and forestry [12-15]. Hydrogels are macromolecular, crosslinked polymers whose dried, tightly wound balls have the form of crystalline grains and after moistening considerably enlarge their volume, taking the form of gel. During moistening, Hydrogel activity in soil causes amide functional groups in the cross-linked chains to undergo solvation and disassociation. $\mathrm{K}^{+}$cations also detach, whereas negative charges of a polymer chain push off under the influence of electrostatic forces. This causes loosening of polymer balls, which get a possibility for further water absorption and gel formation. The swelling gel absorbs water until polymer chains forming a spatial network will elongate maximally. Hydrogel swelling during moistening causes loosening of soil mass and an increase in general porosity [2]. A specific characteristic of hydrogels is potential absorption and retention of water and returning it to plants when it is necessary during drought. Depending on chemical structure and conditions of their application, hydrogels absorb considerable amounts of water and return it in the way best available to plants. More than $90 \%$ of the retained water is available to plants. The repeatable process of swelling and shrinking of superabsorbent under the influence of water causes loosening of structure and increased substratum aeration, but also better plant supply with water and its lower use through, among other things, improving retention and diminishing substratum evaporation $[2,16]$. Moreover, as demonstrated by numerous studies, hydrogels are harmless to plants, soil organisms, and groundwater [17].

The aim of our research was to assess the effect of Agroaquagel hydrogel on changes of hydrophysical and biological properties of the unproductive areas of chemically degraded soil and tailings. Improvement of hydrophysical and biological properties of the unproductive areas is important for their management.

\section{Materials and Methods}

\section{Scheme of the Experiment and Chemical Analysis}

The research was conducted in laboratory conditions where two substrata were prepared. The first (P1) was composed of loamy sand soil and hydrogel, the second (P2) was prepared from sand tailings mixed with hydrogel (Table 1). The soil showed a slightly acidic reaction, whereas tailings showed a basic reaction (Table 2). The high $\mathrm{pH}$ value of the tailings was related to tailing flotation technology, which uses the compounds of basic character and the mineralogical composition of the tailings containing significant amounts of carbonate. High contents of zinc and lead (soil) and copper and lead (tailings) were found in the tested materials (Table 2). The soil was sampled from the area under the influence of the Bolesław Mine and Metallurgical
Table 1. Agroaquagel doses applied to the soil (P1) and tailings (P2).

\begin{tabular}{|c|c|c|}
\hline \multirow{2}{*}{ Treatment } & P1 & P2 \\
\cline { 2 - 3 } & \multicolumn{2}{|c|}{ \% in d.m. } \\
\hline 0 & 0 & 0 \\
\hline I & 0.2 & 0.2 \\
\hline II & 0.6 & 0.6 \\
\hline III & 1 & 1 \\
\hline IV & - & 2 \\
\hline
\end{tabular}

Table 2. Properties of the soil (P1) and post-flotation sludge (P2).

\begin{tabular}{|c|c|c|c|}
\hline Parameters & Unit & P1 soil & P2 tailings \\
\hline $\begin{array}{l}\text { Particle size fractions } \\
\text { [in } \mathrm{mm}]\end{array}$ & \multirow{4}{*}{$\%$} & loamy sand* & sand* \\
\hline $2-0.05$ & & 74 & 94 \\
\hline $0.05-0.002$ & & 19 & 6 \\
\hline$<0.002$ & & 7 & 0 \\
\hline Hygroscopic water & $g \cdot g^{-1}$ & 0.017 & 0.005 \\
\hline $\mathrm{pH}_{\mathrm{KCl}}$ & - & 5.98 & 8.07 \\
\hline $\mathrm{Zn}$ & \multirow{6}{*}{$\mathrm{mg} \cdot \mathrm{kg}^{-1}$} & 740 & 53.13 \\
\hline $\mathrm{Cu}$ & & 2.57 & 864 \\
\hline $\mathrm{Ni}$ & & 2.87 & 21.19 \\
\hline $\mathrm{Cr}$ & & 0.30 & 5.28 \\
\hline $\mathrm{Pb}$ & & 203 & 200 \\
\hline $\mathrm{Cd}$ & & 5.50 & 1.00 \\
\hline
\end{tabular}

*According to FAO 1990 [34].

Plant. The tailings were collected from the Żelazny Most post-flotation waste landfill owned by KGHM Polish Copper S.A., located between Lubin and Głogów. The soil and tailings were collected from a depth of 0-20 cm using a soil core sampler. AgroAquaGel, produced by Artagro in Cracow, was used in the experiment. AgroAquaGel is an acrylic/acrylamide copolymer in the form of crystal grains of up to $2 \mathrm{~mm}$. The capacity of deionised water absorption obtained by the authors of the presented research was 283 $\mathrm{cm}^{3} \cdot \mathrm{g}^{-1} .10$ averaged samples of soil and tailings were collected for laboratory analyses. The granulometric compositions were determined using Bouyoucose-Casagrande's aerometric method in Pruszyński's modification [18], $\mathrm{pH}_{\mathrm{KCl}}$ by potentiometric method, hygroscopic water content, and total content of select elements $(\mathrm{Zn}, \mathrm{Cu}, \mathrm{Ni}, \mathrm{Pb}$, and $\mathrm{Cd}$ ) after digestion in a mixture of $3: 2 \mathrm{HNO}_{3}$ and $\mathrm{HClO}_{4} v / v$ acids in an ICP-OAS apparatus (Pekin Elmer Optima 7300 DV) [19]. Granulation, soil, and tailing properties are presented in Table 2. 
Table 3. Maximum water capacity and water losses in the soil (P1) and tailings (P2) enriched with various amounts of Agroaquagel.

\begin{tabular}{|c|c|c|c|c|c|}
\hline \multirow{2}{*}{ Substrata } & Dose of hydrogel & $\begin{array}{l}\text { Maximum water } \\
\text { capacity }\end{array}$ & $\begin{array}{l}\text { Time when } 50 \% \text { loss } \\
\text { of water occurred }\end{array}$ & $\begin{array}{l}\text { The total loss of water } \\
\text { during drying }\end{array}$ & Loss of water \\
\hline & $\%$ & $\mathrm{~g} \cdot \mathrm{kg}^{-1}$ & day & $\mathrm{g} \cdot \mathrm{kg}^{-1}$ & $\%$ \\
\hline \multirow{4}{*}{ P1 } & 0 & $413.5^{\text {a* }}$ & 6 & $396.9^{\mathrm{a}}$ & 96 \\
\hline & 0.2 & $604.4^{b}$ & 9 & $529.5^{\mathrm{b}}$ & 88 \\
\hline & 0.6 & $1004.5^{\mathrm{c}}$ & 15 & $519.8^{\mathrm{b}}$ & 52 \\
\hline & 1 & $1340.3^{\mathrm{d}}$ & 20 & $568.9^{b}$ & 42 \\
\hline \multirow{5}{*}{$\mathrm{P} 2$} & 0 & $297.2^{\mathrm{a}}$ & 3 & $296.3^{\mathrm{a}}$ & 100 \\
\hline & 0.2 & $332.8^{\mathrm{a}}$ & 6 & $331.5^{\mathrm{a}}$ & 100 \\
\hline & 0.6 & $415.6^{\mathrm{a}}$ & 7 & $412.8^{\mathrm{b}}$ & 99 \\
\hline & 1 & $506.8^{\mathrm{ab}}$ & 8 & $455.7^{b}$ & 90 \\
\hline & 2 & $691.7^{\mathrm{b}}$ & 15 & $462.3^{\mathrm{b}}$ & 67 \\
\hline
\end{tabular}

*homogeneous groups according to the Tukey test, $\alpha<0.05$.

\section{Experiments}

Hydrophysical and biological properties of the substrata were tested in experiments I, II, and III. In experiment I, the effect of the Agroaquagel dose on soil water retention was studied. For this purpose, Kopecky's cylinder was filled with soil and tailings mixed with increasing hydrogel doses (as per the experimental design). Subsequently, the cylinder was placed for $24 \mathrm{hrs}$ in a basin with distilled water. After that time, the cylinder was put on filter paper to enable the outflow of free water. The amount of absorbed water was calculated on the basis of the difference between weights. The test was conducted in three replications for each treatment.

The effect of hydrogel dose on changes in moisture, rate of soil and tailings drying, and differentiation of soil water constants was studied in experiment II. Therefore, an incubation experiment was conducted in which $200 \mathrm{~g}$ soil samples were mixed with various doses of hydrogel and placed in polyethylene containers with a capacity of $500 \mathrm{~cm}^{3}$. On day zero, the soils with hydrogels were saturated with water to maximum water capacity. The experiment was conducted for 25 days at $23^{\circ} \mathrm{C}$. On each day of the incubation, the container was weighed to monitor water losses. The experiment was conducted in three replications for each experimental treatment. The following analyses were carried out in P1 and P2 substrata:

- Maximum water content in pots soils (MWCP), showed as gravimetric water content

- The time by which $50 \%$ water loss occurred

- Total water loss during the drying period

- The rate of soil and tailings drying; in order to determine the rate of drying, a percent decrease in water content was computed during the subsequent days of the measurement in relation to water content in the soil/ tailings on the first day of the measurement (ater content on the first day was assumed to be $100 \%$ ).

- Soil water constants were determined by means of Richards porous plates in pressure cells: maximum water capacity (MWC) moisture at $-0.1 \mathrm{kPa}$ potential, field water capacity (FWC) equal to the moisture at $-9.81 \mathrm{kPa}$ potential, and permanent wilting point (PWP) at the potential of $-1,558.1 \mathrm{kPa}$ - equal to the retention of water unavailable to plants; on the basis of these water contents, drainage capacity $(\mathrm{DC}=\mathrm{MWC}-\mathrm{FWC})$ and retention of water available for plants (WAP= FWC - PWP) were calculated. The samples for these analyses were prepared in cylinders with a capacity of $100 \mathrm{~cm}^{3}$, to which soil with hydrogel supplement was poured in the amount corresponding to the bulk density of soils in a pot experiment (i.e. $65 \mathrm{~g}$ for P1 and $80 \mathrm{~g}$ of soil for P2).

Biological properties of the substrata were studied in experiment III. Biological properties of the substrata were investigated on the basis of germination and initial growth of the test plant Lepidium sativum during the drought period lasting 20 days. Lepidium sativum was used in the experiment because this plant is a fast grower. The experiment was conducted in $500 \mathrm{~cm}^{3}$ containers (Table 1). Fifteen seeds of Lepidium sativum were sown into each container. After sowing, the substrata were soaked with distilled water to maximum water capacity. The experiment was conducted in three replications. The test plant was not watered during the 20 days of the experiment duration.

The obtained results were elaborated upon statistically using one-way analysis of variance. The significance of differences was verified by Tukey's test at significance level of $\alpha=0.05$ using the Statistica 9.0 program.

\section{Results and Discussion}

Agroaquagel hydrogel mixed with soil (P1) markedly increased its maximum water capacity (Table 3 ). In relation to the control, MWCP of P1 increased by $32 \%$ at $0.2 \%$ hydrogel dose, by $59 \%$ at $0.6 \%$ dose, and by $69 \%$ at $1 \%$ dose. In tailings (P2), a significant increase in MWCP occurred only in the case of the $2 \%$ hydrogel dose (Table 3 ). 
The MWCP of P2 was also dependent on the hydrogel dose. It increased by $11 \%, 28 \%, 41 \%$, and $57 \%$ for $0.2 \%$, $0.6 \%, 1 \%$, and $2 \%$ doses, respectively, in comparison with the control.

Table 3 and Figs. 1-2 present the effect of hydrogel dose on water losses during the 20-day long period of drying. In P1 substratum, a 50\% loss of maximum water capacity was first revealed at the time, respectively, from six days in the control object without the supersorbent addition to 20 days at $1 \%$ dose (Table 3 ). The tailings (P2) lost water faster than the soil (P1) (Table 3). MWCP of the tailings decreased by $50 \%$ on the third day in the control treatment, and on the $15^{\text {th }}$ day in the treatment with the highest hydrogel dose, i.e. $2 \%$ (Table 3 ). After 25 days of drought stress (depending on the hydrogel dose), water loss in P1 ranged between 42 and $96 \%$, while in P2 between 60 and 100\% (Table 3).

The rate of soil and tailings drying was calculated as a percent decline in water content over the subsequent days of the investigated period in relation to water content measured at the beginning of the period assumed as $100 \%$ (Figs. 1 and 2). In P1, the highest decline in water content occurred in the control treatment for $0.2 \%$ hydrogel dose on days 7 and 13 of the experiment, for the $0.6 \%$ dose on day 13 , and for the $1 \%$ dose a decrease in water content was noted only in the initial period, whereas in the later period changes in drying rate were very low (Fig. 1). In P2 substratum, the highest hydrogel dose proved the most efficient for water content maintenance. The other hydrogel doses caused faster drying of this substratum and had less influ- ence on drying dynamics (Fig. 2). The comparison of the tailings drying rate revealed that initially for variants $0,0.2$, 0.6 , and $1 \%$ hydrogel doses, loss of water content was high. The tailings in the variant with $2 \%$ Agroaquagel addition revealed a lower rate of drying at that time. The highest loss of water content in the control treatment and in the treatment with $0.2 \%$ supersorbent supplement was revealed on days 7 and 9 of the experiment, whereas in the other variants, on day 13 of drought.

Agroaquagel addition affected an improvement in water retention capacity in the studied P1 and P2 (Table 4). Increasing hydrogel doses were accompanied by significant increases at MWC and WAP, whereas DC significantly decreased in relation to the control treatment (Table 4).

Due to their texture, both P1 and P2 substrata without hydrogel supplements were characterized by high DC and low retention of WAP water available for plants. Their texture also determined a low retention of PWP (Table 4). In both substrata, hydrogel supplement caused differentiation of hydrophysical properties between the substrata with various hydrogel shares. BD of P1 and P2 increased significantly, corresponding to growing hydrogel share (Table 4). Increases in MWC and FWC took place in substrata P1. A bigger share of hydrogel in both substrata caused a significant increase in WAP (Table 4). The increased hydrogel share also caused a higher retention of PWP, although the highest where at $1.0 \%$ supplements in $\mathrm{P} 1$ substratum and $1.0 \%$ and $2.0 \%$ additions in $\mathrm{P} 2$ substratum, causing a marked increase in this category of water availability.

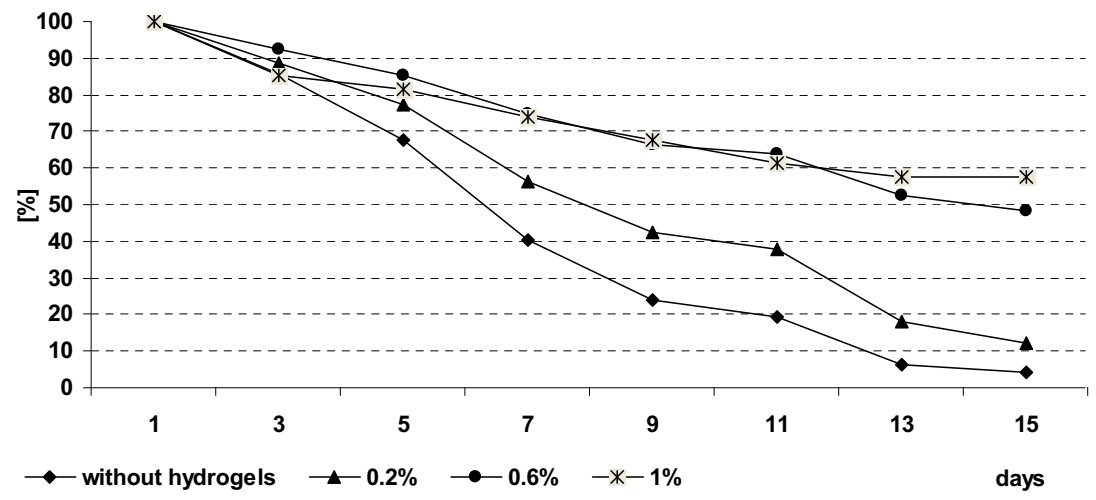

Fig. 1. Rate of drying of the soil (P1) amended with various Agroaquagel doses during the 15-day period.

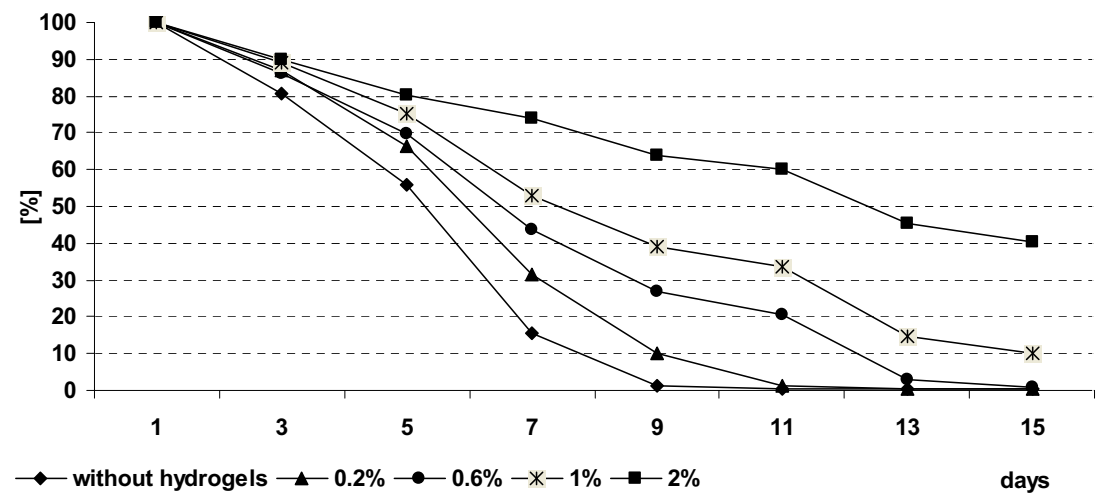

Fig. 2. Rate of drying of the tailings (P2) amended with various Agroaquagel doses during the 15-day period. 
Table 4. Bulk density and water properties in the soil (P1) and the tailings (P2) enriched with various doses of Agroaquagel.

\begin{tabular}{|c|c|c|c|c|c|c|c|}
\hline \multirow{3}{*}{ Substrata } & \multirow{2}{*}{$\begin{array}{c}\text { Dose of } \\
\text { hydrogel }\end{array}$} & \multicolumn{5}{|c|}{ Water capacity } & \multirow{2}{*}{$\mathrm{BD}$} \\
\hline & & MWC & WFC & PWP & WAP & DP & \\
\hline & {$[\%]$} & \multicolumn{5}{|c|}{$\left[\mathrm{m}^{3} \cdot \mathrm{m}^{-3}\right]$} & {$\left[\mathrm{Mg} \cdot \mathrm{m}^{-3}\right]$} \\
\hline \multirow{4}{*}{ P1 } & 0 & $0.515^{\mathrm{a} *}$ & $0.322^{\mathrm{a}}$ & $0.052^{\mathrm{a}}$ & $0.270^{\mathrm{a}}$ & $0.119^{\mathrm{a}}$ & $1.29^{\mathrm{a}}$ \\
\hline & 0.2 & $0.556^{\mathrm{b}}$ & $0.408^{b}$ & $0.057^{\mathrm{ab}}$ & $0.350^{\mathrm{b}}$ & $0.148^{b}$ & $1.19^{\mathrm{b}}$ \\
\hline & 0.6 & $0.601^{c}$ & $0.450^{\mathrm{c}}$ & $0.062^{\mathrm{b}}$ & $0.388^{c}$ & $0.151^{\mathrm{b}}$ & $1.15^{\mathrm{c}}$ \\
\hline & 1.0 & $0.775^{\mathrm{d}}$ & $0.553^{\mathrm{d}}$ & $0.072^{\mathrm{c}}$ & $0.481^{\mathrm{d}}$ & $0.222^{c}$ & $0.89^{\mathrm{d}}$ \\
\hline \multirow{5}{*}{ P2 } & 0 & $0.447^{\mathrm{a}}$ & $0.181^{\mathrm{a}}$ & $0.016^{\mathrm{a}}$ & $0.165^{\mathrm{a}}$ & $0.265^{\mathrm{a}}$ & $1.63^{\mathrm{a}}$ \\
\hline & 0.2 & $0.493^{\mathrm{a}}$ & $0.174^{\mathrm{a}}$ & $0.015^{\mathrm{a}}$ & $0.159^{\mathrm{a}}$ & $0.319^{\mathrm{a}}$ & $1.57^{\mathrm{b}}$ \\
\hline & 0.6 & $0.576^{\mathrm{b}}$ & $0.185^{\mathrm{a}}$ & $0.016^{\mathrm{a}}$ & $0.169^{\mathrm{a}}$ & $0.391^{\mathrm{b}}$ & $1.52^{\mathrm{c}}$ \\
\hline & 1.0 & $0.700^{c}$ & $0.299^{\mathrm{b}}$ & $0.023^{b}$ & $0.275^{\mathrm{b}}$ & $0.401^{\mathrm{bc}}$ & $1.47^{\mathrm{d}}$ \\
\hline & 2.0 & $0.927^{\mathrm{d}}$ & $0.465^{\mathrm{c}}$ & $0.112^{\mathrm{c}}$ & $0.353^{\mathrm{c}}$ & $0.462^{\mathrm{c}}$ & $1.42^{\mathrm{e}}$ \\
\hline
\end{tabular}

*MWC - maximum water capacity, WFC - water field capacity, PWP - permanent wilting point, DP - drainage capacity, WAP - water available for plants, $\mathrm{BD}$ - bulk density.

*homogeneous groups according to the Tukey test, $\alpha<0.05$.

The research did not demonstrate any significant effect of the hydrogel supplement on germination of Lepidium sativum seeds. It shows that both in the control treatments and those with different hydrogel doses, test plant seeds had similar water conditions, at least at the beginning of their growth period. Germination of Lepidium sativum occurred after 2-3 days, irrespective of hydrogel dose (Table 5). The research conducted by Akhter et al. [7] also demonstrated that germination of wheat and barley plants does not depend on hydrogel addition to the soil, although a better growth of both plant species is stimulated in hydrogel presence in soil. The research conducted by Rehman et al. [20] showed that the application of hydrogel improved soil moisture content as compared to the soil without hydrogel. More water availability met the crop water needs and increased the number of germinated seeds of rice.

The presented investigations revealed that in drought conditions, young plants without hydrogel in substrata 1 and 2 were able to survive for a maximum of five days, whereas in the treatment with a $0.2-1 \%$ hydrogel supplement survival was up to 15 days for P1 and 10 days for P2 (Figs. 3 and 4). As a result, the period of plant survivability extended by c.a. $66 \%$ for the soil and by $39 \%$ for the tailings. Bartnik [21] obtained similar results in his research, which revealed that pine seedlings in drought conditions were able to survive in the soil without hydrogel for a maximum of 15 days, whereas with the hydrogel addition after 18 days of drought most seedlings still remained alive. The author demonstrated that the pine seedling survivability period extended by some $50 \%$ in comparison with seedlings in the soil without hydrogel. Al-Humiad [22] obtained similar results while investigating the effect of hydrogel on the survivability of Conocarpus erectus L. seedlings in conditions of water stress. Al-Humid found that hydrogel supplements prolonged the period of water loss by $66 \%$ in comparison with the control. On the other
Table 5. Effects of Agroaquagel supplement in the soil (P1) and tailings (P2) on germination of Lepidium sativum seeds.

\begin{tabular}{|c|c|c|}
\hline \multirow{2}{*}{$\begin{array}{c}\text { Dose of hydrogel } \\
{[\%]}\end{array}$} & P1 & P2 \\
\cline { 2 - 3 } & \multicolumn{2}{|c|}{ Germination of seeds \% } \\
\hline 0 & 90 & 95 \\
\hline 0.2 & 100 & 90 \\
\hline 0.6 & 90 & 95 \\
\hline 1 & 100 & 100 \\
\hline 2 & - & 100 \\
\hline
\end{tabular}

hand, other studies indicate that hydrogel added to soil significantly influences improvement of some biometric properties of seedlings, e.g. height, thickness of the root neck, or root dry mass [23, 24]. Also, the research conducted by Rowe et al. [25] demonstrated that an admixture of hydrogel to the soil results in the improved survivability of willow and alder seedlings in dry and degraded areas. Research conducted by Callaghan et al. [26, 27] also shows that hydrogel amendments in sandy soils promote seedling survival and growth under arid conditions. Contrasting results may be related to the soil texture, thus the hydrogel application in sandy soils promotes an increase in water retention capacity and plant water potential [17], while in loamy and clay soils the effect may be negligible. The effect of an amendment of sandy soil with hydrogel on the survival of Pinus halepensis seedlings during water stress was investigated by Huttermann et al. [23]. Different concentrations of the hydrogel were added to sandy soils at 0.04 , $0.08,0.12,0.20$, and $0.40 \%$ weight by weight. The highest addition $(0.4 \%)$ changed the water retention and its change in water potential with regard to its water content from typ- 
ical sand to a loam or even silty clay. The survival rates in $0.4 \%$ hydrogel were doubled compared to no hydrogel amendments. The hydrogel also allowed for 19 days of drought tolerance.

Analysis of the obtained results allowed us to compare the drying rate of the soil and tailings without the supplement and with various supplements of hydrogel. Hydrogel admixture markedly influenced an increase in water content in the studied substrata and slowed down water loss during the whole period of investigations. The increasing dose was accompanied with increasing water content of the soil (P1) and tailings (P2). The substrata with hydrogel admixture were characterized not only by a higher soil moisture and definitely long-term storage water in the soil, but also by, on average, 2-4 days slower drying rate in comparison with the substrata without hydrogel supplement.

The above-presented results confirm the research conducted by Abedi Koupai et al. [17]. Hydrogel caused the residual water content and saturated water content to increase. Available water content increases to a maximum of about 2.3 times the control [17]. Moreover, substrata with hydrogel addition are characterized by a higher capillary and total water capacity. Hydrogels revealing a high water absorbing ability increase water capacity of the substrata. As has been reported by Owczarzak et al. [28], this effect may be connected with breaking vertical micropores in the substratum, which limits water evaporation, at simul- taneously maintained porosity. According to other studies describing the effect of different doses of hydrophilic polymers $(0,0.1,0.2,0.3$, and $0.4 \%)$ on growth of cucumber seedlings, the ability of water retention in soil increased with increasing polymer dose, although the longer the drought period, the more effective the higher polymer doses. Soils with higher concentrations of hydrogel dry slower, even when their moisture in the initial period is lower $[29,30]$. After some time they reach higher moisture content than soils without the hydrogel admixture. However, at very low hydrogel additions, no significant effect of supersorbent on the soil moisture content is observed. Also, studies conducted in laboratory conditions by Leciejewski [31] on the effect of hydrogel admixture on changes of soil moisture content and rate of sandy soil drying at various depths $(3,8,13$, and $23 \mathrm{~cm})$ yielded some interesting results.

In the research by Leciejewski [31], hydrogel admixture significantly affected increased soil moisture and slowed down water loss at the studied depth of the soil profile during the whole measurement period. Average soil moisture content increased markedly with the increasing depth at which the measurements were conducted. The tendency was also clearly visible at the depth of soil moisture, below the zone of its activity. In research studies conducted by other authors, it was stated that in sandy soil improved with hydrogel dosed at 0.3 and $0.7 \mathrm{mg} \cdot \mathrm{kg}^{-1}$, soil water capacity increased, respectively, by $23 \%$ and

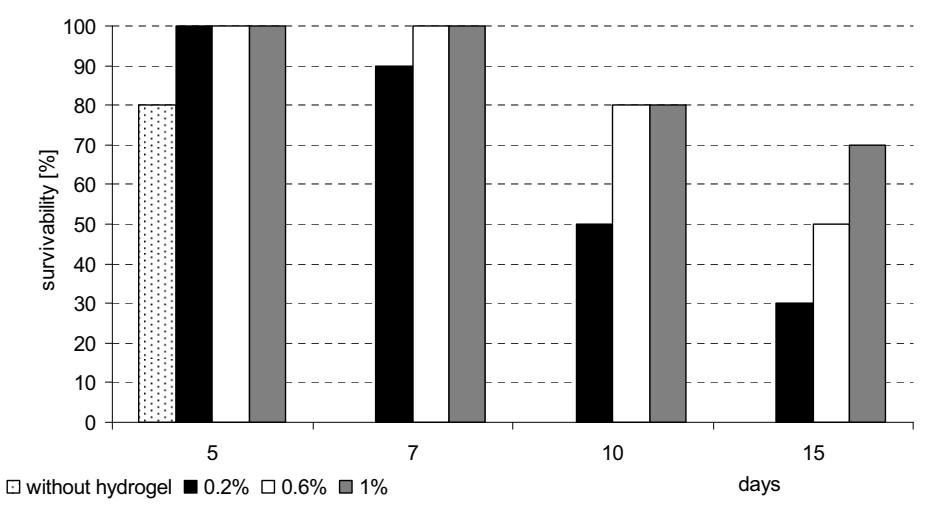

Fig. 3. Effect of various hydrogel doses on survivability of Sinapis alba seedlings in the soil (P1) by reducing drought stress.

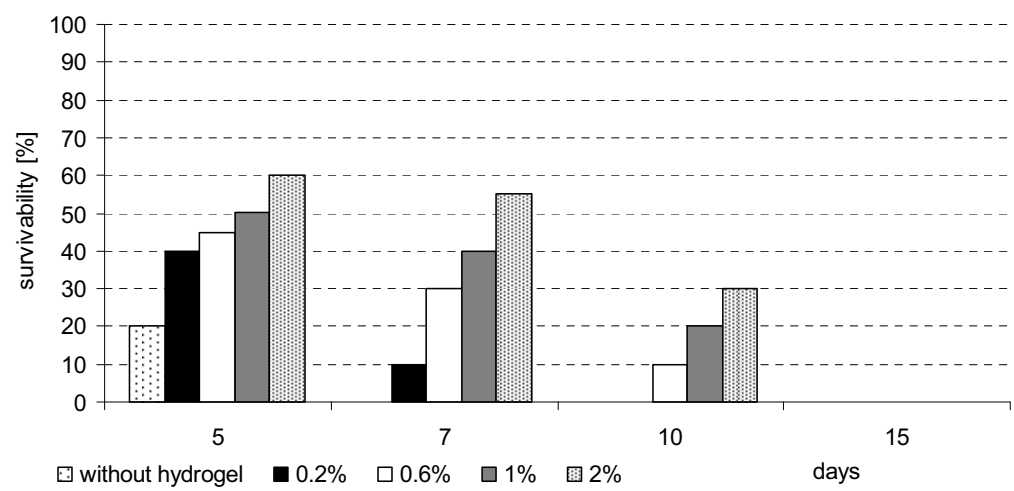

Fig. 4. Effect of various hydrogel doses on survivability of Sinapis alba seedlings in the tailings (P2) by reducing drought stress. 
95\% [32]. Because the moisture causing a permanent wilting point also increased significantly, retention of water available for plants raised only slightly in the soils with hydrogel supplement. On the other hand, Akhter et al. [7] and Abedi-Koupai et al. [17] demonstrated that field water capacity and retention of water available for plants increased proportionately to hydrogel dose. Therefore, the hydrogel application allows for maintaining the proper moisture in the root zone of sandy soils and diminishes water losses caused by its flow into the soil profile, which is very important for recultivation of degraded and unproductive areas $[33,35]$.

In summary, the presented research showed differences in water sorption by the hydrogel in the soil and the tailings. These differences were caused by their texture and chemical properties connected with the content of elements. The tailings were characterized by sand fraction, without content of organic matter and a very high content of elements. These properties could affect the lower water sorption by the hydrogel in the tailings. However, it seems that hydrogels can be used for regeneration of degraded areas.

It should be remembered that in addition to drought in these areas, there are many other plant stressors. One of the most important is substratum salinity, which is an important factor that can affect the activity of hydrogels, because in addition to water they are capable of absorbing cations. Hydrogel matrix saturation by ions of the elements can decrease the effectiveness of water sorption, and effectiveness as an agent preventing drought stress [1, 36]. Hydrogels are recommended as highly effective soil amendment agents. Hydrogels may find wider application in agriculture, forestry, horticulture, and in environmental protection $[4,7,9,16,29,37,38]$. However, due to the high cost of hydrogel applications, its widespread use does not seem to be economically cost-effective [7].

\section{Conclusions}

1. Agroaquagel hydrogel improved hydrophysical and biological properties of the unproductive areas: chemically degraded soil and tailings. All doses of agroaquagel hydrogel mixed with soil increased by 32$69 \%$ of its maximum water capacity. In tailings, a significant increase in maximum water capacity occurred only in the case of the $2 \%$ hydrogel dose.

2. Agroaquagel hydrogel improved water-air properties of the sandy soils and tailings. In both of them (P1 and P2) increased doses of hydrogel caused increases of MWC, PWP, WAP, and DC, and decreases of BD.

3. Soil and tailings enriched with hydrogel supplement revealed a lower rate of drying, which limits the loss of water available to plants.

4. Applied hydrogel positively affected plant growth during drought stress. The plant survivability period during drought was extended by c.a. $66 \%$ in soil and by $39 \%$ in tailings.

\section{Acknowledgements}

The studies was conducted within the framework of the project "Knowledge and practice - the key to success in business." The work was financed by: the subsidy for science DS-3148/KChRiŚ granted by the Polish Ministry of Science and Higher Education.

\section{References}

1. CHEN S., ZOMMORODI M., FRITZ M., WANG S., HTTERMANN A. Hydrogel modified uptake of salt ions and calcium in Populus euphratica under saline conditions. Trees, 18, 175, 2004.

2. PALUSZEK J. Physical quality of eroded soil amended with gel-forming polymer. International Agrophysics, 25, 375, 2011.

3. HAYAT R., ALI S. Water absorption by synthetic polymer (Aquasorb) and its effect on soil properties and tomato yield. International Journal of Agriculture and Biology, 6, 998, 2004.

4. PALUSZEK J. Quality of structure and water-air prosperities of eroded haplic luvisol treated with gel-forming polymer. Pol. J. Environ. Stud., 19, (6), 1287, 2010.

5. BARAN A., ŚLIWKA M., LIS M. Selected properties of flotation tailings wastes deposited in the Gilów and Żelazny Most wastes reservoirs regarding their potential environmental management. Archives of Mining Sciences, 58, (3), 961, 2013.

6. ŚLIWKA M., BARAN A., WIECZOREK J. Evaluation of toxic metal bioaccumulation in a reservoir of flotation tailings. Pol. J. Environ. Stud., 22, (3), 909, 2013.

7. AKHTER J., MAHMOOD K., MALIK K. A., MARDAN A., AHMAD M., IQBAL M. M. Effect of hydrogel amendment on water storage of sandy loam and loam soils and seedling growth of barley, wheat and chickpea. Plant Soil Environment, 50, (10), 463, 2004.

8. AL-HUMAID A. I., MOFTAH A. E. Effects of hydrophilic polymer on the survival of buttonwood seedlings grown under drought stress. J. Plant Nutr., 30, 53, 2007.

9. SARVAŠ M., PAVLENDA P., TAKÁČOVÁ E. Effect of hydrogel application on survival and growth of pine seedling in reclamations. Journal of Forest Science, 53, (5), 204, 2007.

10. PTACH W., BOCZOŃ A., WRÓBEL M. The use of hydrogel in afforestation of postindustrial areas. Journal of Water and Land Development, 13b, 125, 2009.

11. YANG J., WANG F., TAN T. Synthesis and characterization of a novel soil stabilizer based on biodegradable poly (aspartic acid) hydrogel. Korean J. Chem. Eng., 25, 1076, 2008.

12. BAASIRI M., RYAN J., MUCHEIK M., HARIK S.N. Soil application of a hydrogel conditioner in relation to moisture, irrigation frequency and crop growth. Commun. Soil Sci. Plan. 17, 573, 1986.

13. KIM S., IYER G., NADARAJAH A., FRANTZ J.M., SPONGBERG A.L. Polyacrylamide hydrogel properties for horticultural applications. Int. J. Polym. Anal. Ch., 15, (5), 307, 2010.

14. ABEDI KOUPAI J., ESLAMIAN S.S., KAZEMI J.A. Enhancing the available water content in unsaturated soil zone using hydrogel, to improve plant growth indices. Ecohydrology and Hydrology, 8, (1), 67, 2008. 
15. BHARDWAJ A.K., SHAINBERG I., GOLDSTEIN D., WARRINGTON D.N., LEVY G.J. Water retention and hydraulic conductivity of cross-linked polyacrylamides in sandy soils. Soil Sci. Soc. Am. J., 71, 406, 2007.

16. PALUSZEK J. Effect of addition of Agroaquagel 420 on physical properties of eroded luvisol. Environment Protection Natural Resource, 44, 107, 2010 [In Polish].

17. ABEDI-KOUPAI J., SOHRAB F., SWARBRICK G. Evaluation of hydrogel application on soil water retention characteristics. J. Plant Nutr., 31, (2) 317, 2008.

18. MUSIEROWICZ A. Mechanical composition of the soil and methods of mechanical analysis. PWIR, Warszawa, 81102, 1949 [In Polish].

19. OSTROWSKA A., GAWLIŃSKI S., SZCZUBIAŁKA Z. Methods of analysis and assessment of soil properties and plant, first ed., Institute of Environmental Protection, pp. 333, 1991 [In Polish].

20. REHMAN A., AHMAD R., SAFDAR M. Effect of hydrogel on the performance of aerobic rice sown under different techniques. Plant, Soil and Environment, 57, (7), 321, 2011.

21. BARTNIK CZ. The influence of hydrogel on the survival rate of seedlings and the plants of Pinus sylvestris L. during drought. Studia i Materiały Centrum Edukacji Przyrodniczo-Leśnej, 10, 2, 18, 329-338, 2008 [In Polish].

22. AL-HUMAID A.I. Effects of hydrophilic polymer on the survival of bottonwood (Conocarpus erectus) seedlings grown under drought stress. European Journal of Horticultural Science, 3, 2005 [Summary in English].

23. HUTTERMANN A., ZOMMORODI M., REISE K. Addition of hydrogels to soil for prolonging the survival of Pinus halepensis seedlings subjected to drought. Soil Till. Res., 50, 295, 1999.

24. ABEDI-KOUPAI J., SOHRAB F. Evaluating the application of superabsorbent polymers on soil water capacity and potential on three soil textures. Iranian Journal of Polymer Science and Technology, 17, 163, 2004.

25. ROWE E.C., WILLIAMSON J. C., JONES D. L., HOLLIMAN P., HEALEY J. R. Initial tree establishment on block quarry waste ameliorated with hydrogel or slate processing fines. J. Environ. Qual., 34, 994, 2005.

26. CALLAGHAN T.V., ABDELNOUR H., LINDLEY D.K. The environmental crisis in the Sudan: the effect of waterabsorbing synthetic polymers on tree germination and early survival. J. Arid Environ., 14, 301, 1988.

27. CALLAGHAN T.V., LINDLEY D.K., ALI O.M., ABDELNOUR H., BACON P.J. The effect of water-absorbing synthetic polymers on the stomatal conductance, growth and survival of transplanted Eucalyptus microtheca seedlings in the Sudan. J. Appl. Ecol., 26, 663, 1989.

28. OWCZARZAK W., KACZMAREK Z., SZUKAŁA J. The influence of stockosorb hydrogel on selected structure-forming properties of gray-brown podzolic soil land black earth. Journal of Research Applications in Agricultural Engineering, 51, (3), 55, 2006

29. MARTYN W., ONUCH-AMBORSKA J. Assessment of of drying rate on horticultural substrates depending on their part in the the hydrogel. Advances of Agricultural Science Problem Issues, 461, 291, 1998 [In Polish].

30. MARTYN W., SZOT P. Influence of superabsorbents on the physical properties of horticultural substrates. International Agrophysics, 15, 87, 2001.

31. LICIEJEWSKI P. The influence of the hydrogel addition on the changes of the sandy soil's moisture and the dynamics of soil drying in the laboratory conditions. Studia i Materiały Centrum Edukacji Przyrodniczo-Leśnej, 10, 2, 18, 317-328, 2008 [In Polish].

32. SIVAPLAN S. Benefits of treating sandy soil with a crosslinked-type polyacrilamide. Aust. J. Exp. Agr., 46, 579, 2006.

33. HÜTTERMANN A., ORIKIRIZA L.J.B., AGABA H. Application of Superabsorbent Polymers for Improving the Ecological Chemistry of Degraded or Polluted Lands. CLEAN - Soil, Air, Water, 37, (7), 517, 2009.

34. FAO-ISRIC. Guidelines for profile description. $3^{\text {rd }}$ Edition. Rome, 1990.

35. NARJARY B., AGGARWAL P., SINGH A., CHAKRABORTY D., SINGH R. Water availability in different soils in relation to hydrogel application. Geoderma, 187-188, 94, 2012.

36. HADAM A., KARACZUN Z. Salinity effect on to the turf grass species cultivated with hydrogel addition. Biuletyn Instytutu Hodowli i Aklimatyzacji Roślin. 256, 113, 2011.

37. SARUCHI, KAITH B.K., JINDAL R., KAPUR G.S. Enzyme-based green approach for the synthesis of gum tragacanth and acrylic acid cross-linked hydrogel: its utilization in controlled fertilizer release and enhancement of water-holding capacity of soil. Iran. Polym. J., 22, (8), 561, 2013.

38. RASHIDZADEH A., OLAD A., SALARI D., REYHANITABAR A. On the preparation and swelling properties of hydrogel nanocomposite based on Sodium alginate-g -Poly (acrylic acid-co-acrylamide)/Clinoptilolite and its application as slow release fertilizer. Journal of Polymer Research, 21, 344, 2014. 